\title{
BUDIDAYA UDANG VANAME POLA INTENSIF DENGAN SISTEM BIOFLOK DI TAMBAK
}

\author{
Gunarto, Hidayat Suryanto Suwoyo, dan Bunga Rante Tampangallo \\ Balai Penelitian dan Pengembangan Budidaya Air Payau \\ Jl. Makmur Dg. Sittaka No. 129, Maros 90512, Sulawesi Selatan \\ E-mail:gunasrtom@yahoo.com
}

(Naskah diterima: 5 April 2012; Disetujui publikasi: 24 September 2012)

\begin{abstract}
ABSTRAK
Budidaya udang vaname intensif sistem bioflok merupakan satu di antara beberapa upaya untuk efisiensi biaya produksi, karena bioflok dapat dimanfaatkan sebagai subsitusi pakan bagi udang vaname yang dibudidayakan. Tujuan penelitian adalah untuk mengetahui pengaruh penambahan sumber C-karbohidrat (molase) sebagai upaya penumbuhan bioflok pada budidaya udang vaname pola intensif di tambak terutama efeknya pada pertumbuhan, sintasan dan produksi udang. Dua petak tambak masing-masing ukuran $3.520 \mathrm{~m}^{2}$ dan $3.946 \mathrm{~m}^{2}$ ditebari benur vaname dengan padat tebar $75 \mathrm{ekor} / \mathrm{m}^{2}$. Satu petak sebagai tambak kontrol tanpa penambahan sumber Ckarbohidrat (tambak A) dan satu petak tambak lainnya setelah satu bulan pemeliharaan maka sumber C karbohidrat (molase) mulai ditebarkan ke air tambak (tambak B) tujuannya untuk meningkatkan $\mathrm{CN}$ ratio menjadi $>10: 1$ sehingga diharapkan bioflok mudah tumbuh. Pakan udang diberikan setelah penebaran dengan dosis $100 \%$ dari total biomassa udang pada dua minggu pertama dan setiap dua minggu berikutnya jumlah pakan yang diberikan menurun hingga mencapai dosis 2,5\% dari total biomassa udang setelah udang mencapai masa pemeliharaan bulan keempat. Pada petak yang ditumbuhkan bioflok dosis pakan yang diberikan ke udang dikurangi hingga mencapai $10 \%-20 \%$ dari porsi yang seharusnya diberikan. Sintasan, produksi, dan nilai konversi pakan dihitung setelah udang dipanen. Kualitas air (salinitas, $\mathrm{pH}$, dan oksigen terlarut) di-monitor setiap hari. Total Suspended Solid (TSS), Volatil Suspended Solid (VSS), dan volume bioflok di-monitor setelah terbentuk di air tambak. Total haemosit dan prophenol oksidase udang dihitung pada udang sampel dilakukan menjelang udang dipanen. Hasil penelitian menunjukkan bahwa di tambak B yang ditambahkan sumber C-karbohidrat (ditumbuhkan biofloknya) diperoleh nilai konversi pakan udang lebih rendah daripada yang diperoleh di tambak A. Sintasan dan produksi udang di tambak B lebih tinggi daripada sintasan dan produksi udang di tambak A (kontrol). Total haemosit dan prophenol oksidase lebih tinggi pada udang yang hidup di tambak B yang ditumbuhkan floknya daripada yang diperoleh di tambak A (kontrol).
\end{abstract}

KATA KUNCl: sumber C-karbohidrat, sintasan, produksi, konversi pakan, udang vaname

ABSTRACT: Intensive of white shrimp, L. vannamei pond culture with biofloc systems in brackishwater pond. By: Gunarto, Hidayat Suryanto Suwoyo, and Bunga Rante Tampangallo

Intensive of white shrimp, L. vannamei pond culture with biofloc systems is the one way to make efficient of shrimp cost production, because biofloc is able to used as feed subsitution for L. vannamei cultured. The objective of the research is to know the effect of C-carbohydrate source addition (as the effort to develop biofloc) on 
shrimp growth, survival rate, feed convertion ratio and production in intensive of white shrimp, L. vannamei pond culture. Two rectangular earthern ponds, each size $3,520 \mathrm{~m}^{2}$ and $3,946 \mathrm{~m}^{2}$ were stocked with L. vannamei post larvae day 10 at the density of 75 pieces $/ \mathrm{m}^{2}$. One pond as control pond, without addition C-carbohydrate source ( $A$ pond). The other pond (B pond), after one month shrimp cultured was started to add C-carbohhydrate source to enhance $C N$ ratio in pond waters up to 10:1, which its hoped that biofloc to be easily to develop. Shrimp feed given to the post larvae at the dosage 100\% of total biomass at the first two weeks, and then at every two weeks later, the feed percentages was reduced to attain $2.5 \%$ of total biomass at fourth month of shrimp culture. In biofloc pond (pond B), the feed given to the shrimp was reduced 10\%-20\% from the portion after biofloc develop. Shrimp survival rate, production, and feed convertion were calculated after shrimp harvested. Water quality (salinity, water $\mathrm{pH}$, and dissolved oxygen) was monitored daily. TSS, VSS, and biofloc volume in pond water were monitored. Total haemocyte and prophenol oxidase were calculated at near shrimp harvested. Result of the research showed that the pond with addition of C-carbohidrate source (floc developed in B pond) with lower of feed convertion ratio compared than that of control pond (A pond). Shrimp production and shrimp survival rate was higher in $B$ pond compared than that of $A$ pond. Total haemocyte and prophenol oxidase in shrimp was higher in pond with floc develop (B pond) compared than that of $A$ pond (control pond).

\section{KEYWORDS: C-carbohydrate source, survival, production, feed convertion,} Litopenaeus vannamei

\section{PENDAHULUAN}

Udang putih (Litopenaeus vannamei) mulai diintroduksi dan dibudidayakan pada tahun 1999 dan menunjukkan hasil yang baik, sehingga telah menggairahkan kembali usaha pertambakan di Indonesia. Udang vaname mempunyai keunggulan komparatif dibanding jenis udang budidaya lainnya, antara lain: sintasan udang tinggi (>70\%), ketersediaan benur berkualitas, Spesific Phatogen Free (SPF), dapat dibudidayakan dengan kepadatan tebar tinggi, tahan penyakit, dan konversi pakan rendah (Anonim, 2003; Poernomo, 2004; Gunarto \& Hendrajat, 2008; Gunarto et al., 2009).

Peningkatan produksi udang vaname berkorelasi dengan meningkatnya penggunaan pakan sebagai salah satu faktor produksi utama dalam kegiatan budidaya secara intensif. Alokasi biaya pakan dapat menyerap 60\%-70\% dari total biaya produksi. Dengan semakin mahalnya biaya produksi, maka upaya efisiensi harus dilakukan, satu di antaranya menggunakan teknologi bioflok (Avnimelech, 1999; 2007; Schryver et al., 2008). Prinsip dari teknologi bioflok adalah menumbuhkan mikroorganisme terutama bakteri heterotrof di air tambak yang dimaksudkan untuk menyerap komponen polutan, amoniak yang ada di air tambak dan selanjutnya dikonversi menjadi protein bakteri dan dapat dijadikan sebagai substitusi pakan bagi udang vaname yang dibudidayakan.

Pada teknologi budidaya udang pola intensif agar dapat terbentuk bioflok, maka rasio $\mathrm{C} / \mathrm{N}$ harus ditingkatkan $>10: 1$, kemudian sedikit atau tidak sama sekali dilakukan penggantian air dan diberi aerasi yang kuat dan merata, sehingga oksigen tidak pernah lebih rendah dari $4 \mathrm{mg} / \mathrm{L}$ (Avnimelech, 2009). Untuk meningkatkan rasio $\mathrm{C}: \mathrm{N}$, maka beberapa sumber C-karbohidrat dapat ditambahkan, di antaranya molase (Samocha et al., 2006), tepung tapioka (Hari et al., 2004), glukosa dan gliserol (Ekasari, 2008), sukrosa (Kartika, 2009).

Perubahan rasio $\mathrm{C} / \mathrm{N}$ menjadi $>10: 1$ dalam air tambak akan mengubah sistem dalam tambak yaitu dari autotrof di mana untuk mengendalikan kondisi kualitas air hanya mengandalkan kelimpahan dan keragaman fitoplankton, kemudian berubah menjadi heterotrof yaitu untuk mengendalikan kondisi kualitas air hanya mengandalkan bakteri. Menurut McIntosh (2000), perubahan di tambak udang intensif dari sistem autotrof ke heterotrof terjadi pada minggu ke-9 atau 10 , di mana tanda-tandanya adalah terjadi busa yang biasanya muncul di permukaan air tambak.

Bioflok terdiri atas partikel serat organik yang kaya selulosa, partikel anorganik kalsium karbonat hidrat, biopolymer, bakteria, proto- 
zoa, detritus, ragi, jamur, dan zooplankton (Anonim, 2009). Selanjutnya menurut Tacon et al. (2002), bioflok kaya akan threonin, valin, isoleusin, dan phenilalanin juga tirosin. Sedangkan menurut Mclntosh (2000), kandungan asam amino bioflok terdiri atas arginin, lisin, dan methionin. Gunarto \& Suryanto (2011) mendapatkan 15 jenis asam amino yang terkandung dalam bioflok, dengan persentase yang tinggi yaitu: leusin $(2,32 \%)$, lisin $(1,79 \%)$, dan valin $(1,17 \%)$. Bioflok juga mengandung vitamin yang fungsinya dapat menggantikan vitamin yang disuplai melalui pakan komersial (Tacon et al., 2002) dan enzim yang dapat membantu proses pencernaan pakan pada udang, sehingga udang menjadi tumbuh lebih cepat (Moss et al., 2001). Dengan demikian, apabila dalam tambak telah terbentuk bioflok dan bioflok tersebut dimakan oleh udang, maka akan menghemat pakan yang diberikan pada udang. Saenphon et al. (2005) menyatakan bahwa bioflok mudah terbentuk pada tambak yang menggunakan plastik High Density Polyethylene (HDPE).

Pemanfaatan bioflok pada budidaya udang di tambak di samping untuk mengefisienkan biaya produksi, diharapkan juga mampu meminimalisir risiko serangan penyakit misalnya WSSV, Mio, Vibrio sp., dan lainnya. Pada penelitian ini telah di-monitor total haemosit pada udang yang dibudidayakan. Haemosit pada krustasea berfungsi sebagai sel pagositosis, pengkapsulan dan pemecah (lysis) sel asing yang ada dalam badan udang (Johansen et al., 2000; Bachere, 2000; Gilles $\&$ Haffner, 2000). Tujuan penelitian untuk mengetahui pengaruh penambahan sumber C-karbohidrat (ditumbuhkan bioflok) pada budidaya udang vaname pola intensif di tambak terutama efeknya pada pertumbuhan, sintasan, produksi, dan nilai konversi pakan.

\section{BAHAN DAN METODE}

Penelitian budidaya udang vaname dengan sistem bioflok dilakukan di tambak Balai Penelitian dan Pengembangan Budidaya Air Payau (BPPBAP) di Punaga, Kabupaten Takalar. Dua unit tambak dengan dasar tanah masingmasing ukuran $3.520 \mathrm{~m}^{2}$ (tambak A) dan 3.946 $\mathrm{m}^{2}$ (tambak B) digunakan pada penelitian ini. Tahap persiapan tambak meliputi: pengeringan, pemadatan pelataran tambak, pengapuran, pengisian air, pemupukan, pemasangan kincir, dan penebaran benur vaname dengan padat penebaran 75 ekor $/ \mathrm{m}^{2}$. Pakan komersial yang mengandung protein sekitar 35\% diberikan sejak awal setelah penebaran dengan dosis $100 \%$ dari total biomassa udang, kemudian pakan yang diberikan persentasenya diturunkan setiap dua minggu sekali hingga mencapai $2,5 \%$ dari bobot biomassa udang setelah masuk periode pemeliharaan bulan ke-IV. Selanjutnya dari dua petak tersebut dilakukan upaya sebagai berikut:

A. Satu petak tambak ukuran $3.520 \mathrm{~m}^{2}$ (tambak A) tidak dilakukan upaya untuk menumbuhkan bioflok, tetapi hanya dilakukan penambahan fermentasi probiotik komersial sebanyak $4 \mathrm{mg} / \mathrm{L} / 3$ hari selama masa pemeliharaan

B. Satu petak tambak ukuran $3.946 \mathrm{~m}^{2}$ (tambak B) dilakukan penambahan fermentasi probiotik komersial sebanyak $4 \mathrm{mg} / \mathrm{L} / 3$ hari selama masa pemeliharaan dan diupayakan tumbuh bioflok dengan cara sebagai berikut; setelah satu bulan pemeliharaan, maka di air tambak mulai ditambahkan molase sebagai sumber C-karbohidrat dengan tujuan untuk meningkatkan rasio C:N hingga pada kisaran 12:1. Rasio C:N pakan yang diberikan ke udang, dijadikan dasar berapa seharusnya penambahan molase. Apabila jumlah pakan yang diberikan pada hari ke-60 sebanyak $20 \mathrm{~kg} /$ petak/hari dengan $\mathrm{N}$ pakan $=5,6 \%$; maka jumlah $\mathrm{N}$ sebanyak $1.120 \mathrm{~g}$. C dalam pakan $45 \%$, maka total C dalam pakan $=9.000 \mathrm{~g}$. Dengan demikian rasio $\mathrm{C}: \mathrm{N}$ dalam pakan $=$ 8,035:1. Maka untuk menjadikan $\mathrm{CN}$ rasio dalam air tambak menjadi 12:1, maka sumber C karbohidrat yang ditambahkan ke air tambak yaitu sebanyak $(\mathrm{N}) \times(12-8,035) \times$ $(100 / 45)=1.120 \mathrm{~g} \times 3,964 \times 2,2=9.767$ kg. Selanjutnya apabila jumlah pakan yang diberikan ke udang telah berubah, maka jumlah molase juga akan berubah ditentukan oleh jumlah pakan yang diberikan ke udang dan rasio $\mathrm{C}: \mathrm{N}$ yang diharapkan di air tambak.

Setelah bioflok tumbuh, maka harus dipertahankan kelimpahannya yaitu dengan cara pemberian sumber $\mathrm{C}$ karbohidrat tidak rutin dilakukan setiap hari, tetapi diperlebar selang waktunya menjadi setiap tiga hingga empat hari sekali. Penambahan air dari tandon ke tambak dilakukan hanya untuk mengganti air yang hilang akibat rembesan, evaporasi, atau air yang dibuang. Konsentrasi oksigen terlarut diupayakan selalu di atas $4 \mathrm{mg} / \mathrm{L}$, dengan menambah jumlah kincir apabila diperlukan. 
Apabila di tambak B telah tumbuh bioflok, maka dosis pakan dikurangi sebanyak 10\%$20 \%$ dari dosis pakan standar yang ditetapkan yang diperuntukan pada udang di perlakuan $\mathrm{A}$ (kontrol). Pemberian pakan dengan frekuensi 2-4 x selama 24 jam dan waktu pemeliharaan selama 110 hari.

Peubah yang diamati selama pemeliharaan meliputi pertumbuhan udang yang di-monitor setiap dua minggu. Sedangkan sintasan, produksi, dan konversi pakan dihitung pada akhir penelitian.

Parameter penunjang yang diamati meliputi: salinitas, $\mathrm{pH}$ air, dan oksigen terlarut di-monitor langsung di lapangan.

Setelah bioflok terbentuk di tambak maka dilakukan pengamatan volume bioflok dengan cara mengambil air tambak menggunakan tabung kaca kerucut (Imhoff cone) volume 250 $\mathrm{mL}$, kemudian air dibiarkan selama 15-20 menit agar supaya bioflok mengendap. Selanjutnya dicatat berapa volume bioflok yang mengendap. Di samping itu, juga diambil sampel air tambak A (kontrol) dan tambak B masingmasing sebanyak $200 \mathrm{~mL}$, dibawa ke laboratorium untuk dianalisis nilai Total Suspended Solid dan Volatil Suspended Solid berdasarkan metode di bawah ini: berikut:

Perhitungan TSS dan VSS adalah sebagai

$$
\operatorname{TSS}(\mathrm{mg} / \mathrm{L})=\frac{A-B}{V} \times 100
$$

di mana:
$A=$ Bobot wadah petridish kosong + contoh uji bioflok yang sudah disaring
$B=$ Bobot wadah petridish kosong $(\mathrm{mg})$
$V=$ Volume contoh $(\mathrm{mL})=50 \mathrm{~mL}$
VSS $(\mathrm{mg} / \mathrm{L})=$ TSS - Jumlah abu

Beberapa parameter imun pada udang juga di-monitor yaitu total haemosit dan prophenol oksidase (PO). Pengukuran total haemosit digunakan metode dari Blakxhall \& Daishley (1973). Sampel udang masing-masing sebanyak 15 ekor dari tambak A dan tambak B ditangkap menjelang udang dipanen total untuk diambil haemolimphnya. Pengambilan haemolimph sebanyak $0,1 \mathrm{~mL}$ dari pangkal kaki renang pertama menggunakan syringe steril yang sudah berisi $0,3 \mathrm{~mL}$ antikoagulan Na-sitrat 3,6\%. Campuran dihomogenkan dengan cara menggoyangkan tangan membentuk angka delapan. Tetesan pertama di- buang, selanjutnya diteteskan di haemositometer untuk dihitung jumlah selnya per $\mathrm{mL}$ dengan bantuan mikroskop cahaya binokuler pada pembesaran $400 \mathrm{x}$. Total sel hemosit dihitung menggunakan rumus:

$$
N=\left[\frac{\mathrm{n} 1+\mathrm{n} 2+\mathrm{n} 3+\mathrm{n} 4+\mathrm{n} 5}{5}\right] \times 25 \times 10^{4}
$$

di mana:

$\mathrm{N}=$ Jumlah sel hemosit (sel/mL)

$\mathrm{n} 1, \mathrm{n} 2, \mathrm{n} 3, \mathrm{n} 4, \mathrm{n} 5$ = Jumlah sel hemosit dalam kotak kecil hemositometer

Aktivitas PO diukur berdasarkan formasi dopachrome yang dihasilkan oleh Ldihydroxyphenil alanine (L-Dopa) dengan menggunakan spektrofotometer merk Genesys. Pengukuran aktivitas PO mengacu pada prosedur Liu \& Chen (2004). Sebanyak $0,1 \mathrm{~mL}$ hemolim ditambah dihomogenkan dengan $900 \mathrm{~mL}$ antikoagulan dalam effendorf. Campuran ini kemudian disentrifuge dengan kecepatan $700 \times$ g pada $4^{\circ} \mathrm{C}$ selama 20 menit. Cairan supernatan dibuang dan pelet dibilas dengan $1 \mathrm{~mL}$ cocodilate-citrate buffer $(0,01 \mathrm{M}$ sodium cacodylate, $0,45 \mathrm{M}$ sodium chloride, $0,10 \mathrm{M}$ trisodium citrate, $\mathrm{pH} 7$ ) dan disentrifuge kembali dengan kecepatan dan kondisi yang sama. Supernatan dibuang dan pelet dilarutkan dengan cacodylate buffer (0,01 M sodium cacodylate, 0,45 M sodium chloride, 0,01 M kalsium klorid, 0,26 M magnesium klorid, pH7). Larutan kemudian dibagi dua masing-masing sebanyak $100 \mu \mathrm{L}$. Larutan pertama diinkubasi dengan $50 \mu \mathrm{L}$ trypsin $\left(1 \mathrm{mg} \cdot \mathrm{mL}^{-1}\right.$ cacodylate buffer) sebagai aktivator sedangkan larutan kedua ditambahkan $50 \mu \mathrm{L}$ cacodylate buffer (pengganti tripsin). Kedua-duanya diinkubasi selama 10 menit pada temperatur $25^{\circ} \mathrm{C}-26^{\circ} \mathrm{C}$. Selanjutnya masing-masing ditambah $50 \mu \mathrm{L} \mathrm{L-}$ DOPA ( $3 \mathrm{mg} / \mathrm{mL}$ cacodylate buffer) dan 5 menit kemudian ditambahkan $800 \mu \mathrm{L}$ cacodilate buffer. Aktivitas PO kemudian diukur menggunakan spektrofotometer dengan kerapatan optik adalah absorban $490 \mathrm{~nm}$. Densitas optikal (OD) dari aktivitas PO pada semua kondisi uji dinyatakan sebagai formasi dopachrome dalam $50 \mu \mathrm{L}$ hemolim.

Data pertumbuhan, sintasan, produksi, nilai konversi pakan, total haemosit, dan propenol oksidase dari dua perlakuan yang diuji dibandingkan dan dianalisis menggunakan T test. Data volume bioflok, Total Suspended solid (TSS), Volatil Suspended Solid (VSS) dianalisis secara diskriptif. 


\section{HASIL DAN BAHASAN}

Pertumbuhan udang di petak $A$ (kontrol) nampak lebih tinggi daripada di tambak B (ditumbuhkan bioflok), terutama dari mulai umur pemeliharaan 28 hari hingga panen pada tanggal 24 September 2011 yaitu pada umur pemeliharaan 110 hari (Gambar 1). Pada tambak A, ukuran udang yang dipanen mencapai ratarata $17,80 \mathrm{~g} /$ ekor dengan laju tumbuh harian rata-rata $0,16 \mathrm{~g} /$ hari. Di tambak $\mathrm{B}$, rata-rata ukuran udang yang dipanen 13,38 g/ekor dengan laju tumbuh harian $0,12 \mathrm{~g} /$ hari. Pada penelitian terdahulu dengan padat tebar benur vaname $25 \mathrm{ekor} / \mathrm{m}^{2}$, lama pemeliharaan selama 98 hari diperoleh laju tumbuh harian 0,12-0,17 $\mathrm{g} /$ hari (Gunarto \& Hendrajat, 2008). Pada padat tebar 50 ekor $/ \mathrm{m}^{2}$ dengan lama pemeliharaan 98 hari, diperoleh laju tumbuh harian 0,14-0,15 $\mathrm{g} /$ hari (Gunarto et al., 2009). Subyakto et al. (2008) mendapatkan bobot akhir udang vaname yang lebih besar yaitu pada kisaran 16,67-17,25 g dengan masa pemeliharaan 105 hari. Keadaan yang demikian disebabkan padat tebar 60 ekor $/ \mathrm{m}^{2}$, kondisi tambak dengan salinitas 15-20 ppt, dan kontruksi tambak dengan sistem pembuangan terpusat (central drain). Sedangkan pada penelitian ini, padat tebar lebih lebih tinggi yaitu 75 ekor $/ \mathrm{m}^{2}$ dengan salinitas 35-53 ppt dan konstruksi tambak dengan sistem pembuangan lewat pintu air.

Pertumbuhan udang di tambak B nampak lebih rendah apabila dibanding dengan pertumbuhan udang di tambak A. Berdasarkan monitoring populasi udang pada hari ke-70, telah diketahui bahwa populasi udang di tambak A kurang lebih hanya $50 \%$ dari populasi udang di tambak B. Di tambak B, pada hari ke 84 , bioflok sudah tumbuh, sehingga dosis pakan yang diberikan ke udang di petak $B$ yang seharusnya sebanyak $3 \%$ dari total perkiraan biomassa udang dalam tambak, namun untuk efisiensi hanya diberikan pakan 2,5\% dari total perkiraan berat biomassa udang dalam tambak. Dua hal tersebut yang menyebabkan pertumbuhan udang di tambak B lebih lambat daripada pertumbuhan udang di tambak A. Setelah udang dipanen diperoleh sintasan udang 34,32\% (tambak A) dan 70,72\% (tambak B) (Tabel 1).

Pertumbuhan bioflok di tambak B, nampak cukup padat yaitu mencapai $15 \mathrm{~mL} / \mathrm{L}$, terutama setelah masa pemeliharaan 90 hari dan selanjutnya volume flok diatur agar konstan hingga menjelang panen dengan cara mengatur jumlah dan selang waktu pemberian molase ke tambak hingga hanya setiap tiga/empat hari sekali dan seminggu dua kali dilakukan pembuangan air tambak melalui pintu air, terutama air tambak yang sudah berwarna hitam. Penambahan air dilakukan hanya untuk mengganti air yang keluar dari tambak.

Sintasan udang pada penelitian ini apabila dibandingkan dengan penelitian terdahulu, misalnya budidaya udang vaname dengan aplikasi beberapa jenis probiotik dengan padat

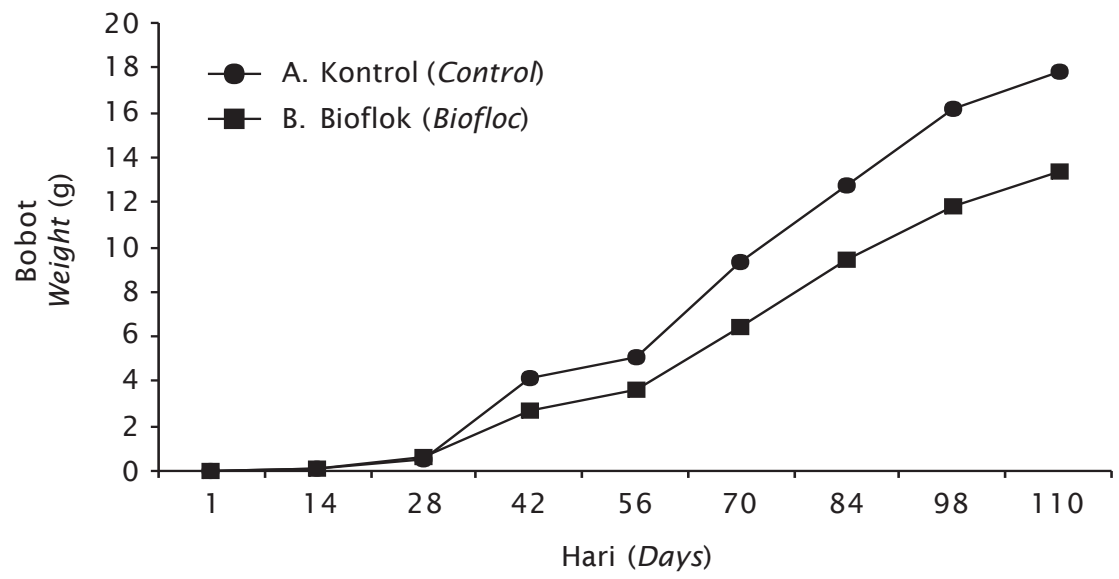

Gambar 1. Pertumbuhan udang vaname selama pemeliharaan 110 hari di tambak kontrol (A) dan tambak dengan sistem bioflok (B)

Figure 1. The growth of vaname during 110 days of culture in control pond (pond $A$ ) and pond with biofloc systems (B) 
Tabel 1. Bobot akhir, sintasan, produksi, dan nilai konversi pakan udang vaname yang dibudidayakan dengan sistem bioflok

Table 1. Final weight, survival, production, and feed convertion ratio of vaname cultured using biofloc systems

\begin{tabular}{|c|c|c|c|c|c|c|}
\hline $\begin{array}{l}\text { Perlakuan } \\
\text { Treatments }\end{array}$ & $\begin{array}{l}\text { Bobot } \\
\text { awal } \\
\text { Initial } \\
\text { weight } \\
\text { (g) }\end{array}$ & $\begin{array}{l}\text { Bobot } \\
\text { akhir } \\
\text { Final } \\
\text { weight } \\
\text { (g) }\end{array}$ & $\begin{array}{c}\text { Sintasan } \\
\text { Survival } \\
\text { rate } \\
\text { (\%) }\end{array}$ & $\begin{array}{c}\text { Produksi } \\
\text { (kg/petak) } \\
\text { Production } \\
\text { (kg/pond) }\end{array}$ & $\begin{array}{c}\text { Produksi } \\
\text { Production } \\
\text { (kg/ha) }\end{array}$ & $\begin{array}{c}\text { Nilai } \\
\text { konversi } \\
\text { pakan } \\
\text { Feed } \\
\text { convertion } \\
\text { ratio }\end{array}$ \\
\hline A & 0.001 & $17.80 \pm 1.73$ & 34.32 & $1,515.50$ & $4,303.96$ & 1.82 \\
\hline B & 0.001 & $13.38 \pm 1.79$ & 70.72 & $2,650.00$ & $6,717.22$ & 1.58 \\
\hline
\end{tabular}

Keterangan (Note):

A. Tanpa upaya penumbuhan bioflok (Without an effort to develop bioflok)

B. Diupayakan tumbuh bioflok (With effort to develop biofloc)

tebar 25 ekor $/ \mathrm{m}^{2}$ yang benurnya diambil dari panti benih di Takalar yang lokasinya hanya dua jam transportasi untuk mencapai tambak, dengan lama pemeliharaan 98 hari mendapatkan sintasan 91\%-96,5\% (Gunarto \& Hendrajat, 2008). Selanjutnya pada budidaya udang vaname dengan dosis probiotik berbeda dengan padat tebar 50 ekor $/ \mathrm{m}^{2}$, benih juga diambil dari panti benih yang sama di Takalar dengan lama pemeliharaan 98 hari diperoleh sintasan 75\%-86\% (Gunarto et al., 2009). Pada penelitian budidaya udang windu pola intensif yang dilakukan pada tahun 2009 benih diambil dari panti benih yang sama juga di Takalar, setelah dibudidayakan di tambak selama 112 hari diperoleh sintasan sebanyak 90\%-99\% (Gunarto et al., 2010a). Pada penelitian budidaya udang windu pola intensif yang dilakukan pada tahun 2010, di mana benur didatangkan dari Kabupaten Barru dengan lama perjalanan $>9$ jam, pada waktu panen hanya diperoleh sintasan 39\%-40\% (Gunarto et al., $2010 \mathrm{~b})$. Sintasan udang yang diperoleh pada penelitian ini cukup rendah baik di tambak $A$ dan B. Hal ini kemungkinan diakibatkan oleh lamanya transportasi benur yang berasal dari panti benih di Situbondo, Jawa Timur, selanjutnya dibawa ke Desa Punaga, Kabupaten Takalar dengan lama transportasi selama $>10$ jam, sehingga menurunkan vitalitas benur.

Penelitian ini berlangsung pada waktu salinitas air tambak cukup tinggi selama pemeliharaan yaitu dari 35 ppt pada waktu tebar, hingga mencapai 53 ppt pada waktu panen. pH air berfluktuasi antara 7,5-8,0. Sedangkan oksigen terlarut pada awal pene- litian di pagi hari jam 7.0 masih $6 \mathrm{mg} / \mathrm{L}$, namun pada saat mendekati panen konsentrasi oksigen paling rendah mencapai $4 \mathrm{mg} / \mathrm{L}$. Udang vaname yang dibudidayakan dengan pola tradisional plus mampu tumbuh baik pada salinitas tinggi (3-53 ppt) (Gunarto \& Mansyur, 2007). Dengan demikian faktor padat tebar dan sintasan udang yang lebih dominan berpengaruh pada kecepatan pertumbuhan udang dari pada salinitas yang tinggi.

Produksi udang di tambak A mencapai $1.515 \mathrm{~kg} /$ petak $(4.303,96 \mathrm{~kg} / \mathrm{ha})$, sedangkan tambak B dengan sistem bioflok mencapai $2.650 \mathrm{~kg} /$ petak $(6.717,22 \mathrm{~kg} / \mathrm{ha})$. Nampak bahwa produksi udang masih rendah karena target produksinya setiap petak 3 ton/petak (7 ton/ha) dengan asumsi bobot udang ratarata $14 \mathrm{~g}$ dan sintasan $80 \%$. Tidak tercapainya target tersebut kemungkinan disebabkan oleh vitalitas benur vaname yang ditebar kurang baik, sehingga menghasilkan sintasan yang rendah. Nilai konversi pakan pada udang dari tambak dengan sistem bioflok (tambak B) juga lebih rendah yaitu hanya $1: 1,58$ dibanding dengan dari tambak $A$, kontrol yaitu 1:1,82 (Tabel 1). Penelitian terdahulu pada budidaya udang vaname dengan padat tebar 25 ekor/ $\mathrm{m}^{2}$ mendapatkan nilai konversi pakan pada kisaran 1,21-1,30 (Gunarto \& Hendrajat, 2008) dan dengan padat tebar 50 ekor $/ \mathrm{m}^{2}$ nilai konversi pakan pada kisaran 1,37-1,69 (Gunarto et al., 2009). Dengan demikian bahwa di tambak $B$, dengan sistem bioflok menyebabkan produksi udang lebih banyak daripada produksi udang di tambak $A$ (kontrol), juga nilai konversi pakan lebih rendah $(1: 1,58)$ di tam- 
bak $B$ dengan sistem bioflok daripada yang diperoleh di tambak A (kontrol) yaitu $(1: 1,82)$. Hal ini karena bioflok juga dimanfaatkan sebagai subsitusi pakan bagi udang vaname yang dibudidayakan. Namun demikian teknologi bioflok tidak selalunya mampu mengefisiensikan pakan, seperti yang dilaporkan oleh Bob Rosenberry (2011) di www. Newshrimp.com bahwa di Belize aquaculture, Amerika, untuk mencapai pertumbuhan udang vaname hingga ukuran 14-15 g, diperlukan nilai konversi pakan lebih dari 2. Hal ini karena digunakan pakan dengan kandungan protein 25\%-28\%, dan terlalu mengandalkan penambahan sumber karbohidrat untuk menumbuhkan bioflok. Sehingga disimpulkan bahwa penambahan karbohidrat seharusnya temporal saja, yaitu pada waktu kandungan amoniak tinggi dan untuk dapat nilai konversi pakan yang rendah, tetap harus digunakan pakan yang berkualitas tinggi namun harus diberikan ke udang secara efisien.

\section{PRODUKSI BIOFLOK}

Hasil monitoring terhadap produksi bioflok di tambak, nampak bahwa pada akhir bulan kedua sebetulnya bioflok sudah terbentuk di tambak B, namun ukurannya masih kecil (Gambar 2 A). Pada akhir bulan ketiga struktur dan ukuran bioflok sudah mulai membesar dan banyak dijumpai protozoa yang mengonsumsi bioflok (Gambar 2b). Menurut Zhi et al. (2008), komponen alga penyusun bioflok terdiri atas diatom, klorofita, sianobakteri, dinoflagelata, dan kriptofita.
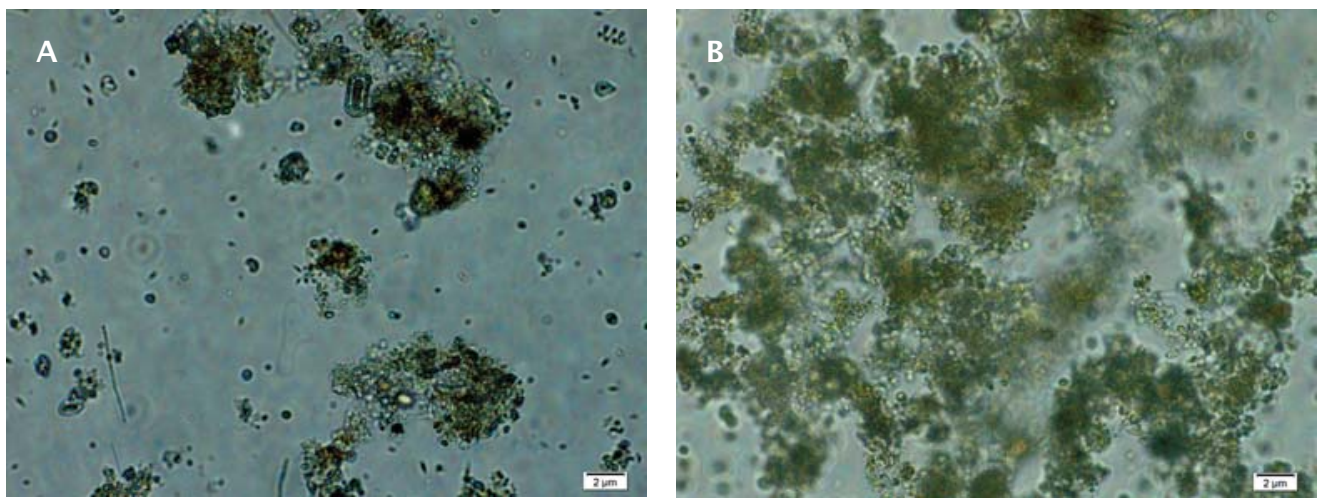

Pada bulan ketiga hingga menjelang panen warna air tambak masih hijau pada perlakuan yang ditumbuhkan biofloknya, namun flok yang terbentuk volumenya sudah cukup padat $15 \mathrm{~mL} / \mathrm{L}$ air tambak. Hal ini berbeda dengan yang dikemukakan oleh Mclntosh (2000) perubahan di tambak udang intensif dari sistem autotrof ke heterotrof terjadi pada minggu ke-9 atau 10, di mana tanda-tandanya adalah terjadi perubahan pada busa yang biasanya muncul di permukaan air tambak menjadi menghilang, warna hijau dari fitoplankton di air tambak berubah menjadi coklat. Berdasarkan pengamatan di tambak budidaya udang vaname pola intensif di Desa Laikang Kabupaten Takalar, dengan padat tebar 150 ekor/ $\mathrm{m}^{2}$ dan jumlah pakan yang diberikan per hari sudah mencapai $200 \mathrm{~kg} /$ petak pada hari ke-90, ternyata bioflok telah terbentuk dengan sendirinya tanpa ada penambahan sumber $C$ karbohidrat ke dalam air tambak, dengan warna air tambak coklat. Sedangkan pada petakan tambak lainnya dengan padat penebaran yang sama dan jumlah pakan yang diberikan per hari juga sama dan dilakukan upaya menumbuhkan bioflok dengan cara selalu ditambahkan molase sebanyak $15 \mathrm{~kg} / 2$ hari, pada hari ke90 bioflok tumbuh padat ( $14 \mathrm{~mL} / \mathrm{L}$ air tambak) dengan warna air tambak hijau. Dengan demikian terdapat beberapa warna bioflok di antaranya coklat dan hijau. Perbedaan warna bioflok disebabkan adanya perbedaan dominasi komponen fitoplankton penyusun bioflok yaitu dominan pigmen klorofil (pigmen primer) untuk bioflok yang berwarna hijau dan karotenoid (pigmen sekunder) untuk bioflok

Gambar 2. Flok yang diperoleh pada umur pemeliharaan udang 70 hari (A) dan flok yang diperoleh pada umur pemeliharaan 105 hari (B)

Figure 2. Floc was develop at the 70 day of culture $(A)$ and floc was develop at the 105 day of culture (B) 
yang berwarna coklat. Menurut fungsinya selama fotosinthesis, pigmen karotenoid diklasifikasikan menjadi dua kelompok yaitu pigmen fotosinthesis misalnya fukokanthin, peridinin, prasinokanthin, beta-karoten, dan pigmen fotoproteksi misalnya antherakanthin, diadinokanthin, dan alokanthin (Zhi et al., 2008).

Kecepatan aktivitas bioflokulasi ditentukan oleh jenis kombinasi mikroorganismenya. Kartika (2009) mendapatkan bahwa kombinasi antara diatom, Chaetoceros sp. dengan bakteri Achromobacter liquefaciens, kemudian Thalassiosira sp. dan Achromobacter liquefaciens merupakan kombinasi terbaik dalam pembentukan bioflok dan kondisi bioflok stabil sampai 7 hari. Kemudian dijelaskan juga bahwa rasio $\mathrm{CN}$ yang paling baik untuk menghasilkan bioflok dan mereduksi amoniak adalah 10:1.

Pada penelitian ini, bakteri yang selalu ditambahkan melalui penambahan fermentasi probiotik komersial yang dilakukan setiap tiga hari sekali dengan tujuan untuk mempercepat terbentuknya bioflok di air tambak adalah didominasi oleh Bacillus subtilis, $B$. cereus, B. megaterium, Pseudomonas sp., dan Aerobacter sp. Bioflok terbentuk di tambak B sejak hari ke-70 dan berwarna hijau. Tidak semua bakteri dapat membentuk bioflok dalam air. Genus Bacillus hanya dua spesies yang mampu membentuk bioflok yaitu Bacillus subtilis dan Bacillus cereus. Bakteri tersebut mensintesa senyawa Polihidroksi alkanoat (PHA), seperti poli $\beta$ hidroksi butirat yang digunakan sebagai bahan polimer untuk pembentukan ikatan polimer antara substansi substansi pembentuk bioflok. Bakteri $B$. subtillis berperan positif pada organisme yang dibudidayakan diantaranya meningkatkan pertumbuhan, sintasan, daya cerna, sistem kekebalan dan kualitas air melalui proses bioremediasi (Matteo et al., 2010). B. subtillis dikombinasikan dengan $B$. licheniformis dan B. pumilis sebagai probiotik dan diaplikasikan pada ikan trout ternyata menghasilkan pertumbuhan yang cepat dan tahan terhadap serangan penyakit (Bagheri et al., 2008). Bacillus subtilis, B. cereus, B. megaterium, Pseudomonas sp. dan Aerobacter sp. sebagai probiotik diaplikasikan pada budidaya udang vaname dengan padat tebar 25-50 ekor/m² mampu memberikan pertumbuhan udang yang baik, sintasan tinggi 75\%-99\% dan menurunkan konsentrasi amoniak di air tambak (Gunarto et al., 2008; 2009). Bakteri lainnya pembentuk bioflok adalah Zooglea ramigera, Escherichia intermedia, Paracolobacterium aerogenoids, Flavobacterium sp., Pseudomonas alcaligenes, Sphaerotillus natans, Tetrad sp., dan Tricoda sp, (Anonimous, 2009).

Adapun efek pertumbuhan bioflok di tambak B pada pertumbuhan udang vaname yang dibudidayakan nampak bahwa meskipun padat tebar lebih tinggi $\left(75 \mathrm{ekor} / \mathrm{m}^{2}\right)$, namun laju tumbuh harian udang tidak jauh berbeda dengan laju tumbuh harian udang vaname yang dibudidayakan dengan padat tebar 25 dan $50 \mathrm{ekor} / \mathrm{m}^{2}$. Namun demikian jelas bahwa masih perlu dilakukan penelitian secara detail untuk mengetahui kombinasi antara bakteri atau probiotik dengan dominan fitoplankton yang tumbuh di tambak untuk menciptakan bioflok yang lebih berkualitas dan disukai udang vaname yang dibudidayakan sehingga mampu mempercepat laju tumbuh udang, meningkatkan produksi dan terjadi efisiensi biaya produksi udang secara nyata. Menurut Schryver et al. (2008), teknologi bioflok merupakan teknologi yang ramah lingkungan karena memproduksi biomassa baru yang terbentuk dari gabungan mikro algae dan bakteri heterotrof yang ditumbuhkan dengan adanya limbah nutrien pada sistem budidaya intensif. Kualitas bioflok yang diharapkan adalah setara dengan pakan buatan yang sekarang banyak digunakan pada budidaya udang vaname intensif. Sehingga untuk melihat kualitas bioflok maka harus diamati kandungan protein, Pollyansaturated Fatty Acid (PUFA), dan lemak merupakan parameter penting sebagai penentu kemungkinan bioflok sebagai pakan dalam budidaya udang/ ikan.

Di tambak A, setelah lebih dari 100 hari pemeliharaan nampak bioflok mulai meningkat volumenya (Tabel 2). Perkembangan bioflok ditandai dengan melimpahnya busa di permukaan air tambak. Hal ini sependapat dengan yang dikemukakan oleh Anonimous (2009) bahwa di tambak budidaya udang pola intensif bioflok akan terbentuk dengan sendirinya. Namun berdasarkan pengamatan di lapangan kecepatan pertumbuhan bioflok dan volumenya yang terbentuk sangat bergantung pada padat tebar udang, jumlah harian pakan yang diberikan ke udang dan sistem aerasi. Apabila jumlah harian pakan yang diberikan ke udang semakin banyak, dikombinasi dengan pemberian fermentasi probiotik komersial 
Tabel 2. Rata-rata volume bioflok yang terbentuk pada tambak kontrol (tambak A) dan tambak dengan sistem bioflok (tambak B)

Table 2. Mean of biofloc volume develop in control pond (pond $A$ ) and pond with biofloc system (pond B)

\begin{tabular}{|c|c|c|}
\hline \multirow[b]{2}{*}{$\begin{array}{c}\text { Tanggal } \\
\text { sampling } \\
\text { Date of } \\
\text { sampling }\end{array}$} & \multicolumn{2}{|c|}{$\begin{array}{l}\text { Volume bioflok yang terbent uk }(\mathrm{mL}) / 1.000 \mathrm{~mL} \text { air tambak } \\
\text { Volume of biofloc }(\mathrm{mL}) / 1,000 \mathrm{~mL} \text { pond water }\end{array}$} \\
\hline & $\begin{array}{l}\text { Tanpa aplikasi sumber } \\
\text { C karbohidrat } \\
\text { Without application of } \\
\text { C carbohydrate source } \\
\text { Petak A (Pond } A \text { ) }\end{array}$ & $\begin{array}{c}\text { Aplikasi sumber C karbohidrat } \\
\text { mulai } 4 \text { Juli } 2011 \\
\text { Application of C carbohydrate } \\
\text { source started at } 4 \text { July, } 2011 \\
\text { Petak B (Pond B) }\end{array}$ \\
\hline $21 / 8$ & 1.0 & 10.2 \\
\hline $23 / 8$ & 1.0 & 11.6 \\
\hline $24 / 8$ & 1.0 & 11.5 \\
\hline $27 / 8$ & 1.0 & 12.8 \\
\hline $29 / 8$ & 1.0 & 12.2 \\
\hline $31 / 8$ & 1.1 & 12.9 \\
\hline $02 / 9$ & 1.2 & 13.9 \\
\hline $04 / 9$ & 1.1 & 13.2 \\
\hline $06 / 9$ & 1.3 & 14.9 \\
\hline $08 / 9$ & 1.6 & 14.7 \\
\hline $10 / 9$ & 1.9 & 14.9 \\
\hline $12 / 9$ & 1.2 & 15.1 \\
\hline $14 / 9$ & 1.4 & 15.1 \\
\hline $16 / 9$ & 1.5 & 15.0 \\
\hline $18 / 9$ & 1.1 & 15.2 \\
\hline $20 / 9$ & 2.0 & 15.3 \\
\hline $22 / 9$ & 2.1 & 15.5 \\
\hline Rataan (Average) $(\mathrm{mL} / \mathrm{L})$ & $1.323 \pm 0.37^{a}$ & $13.764 \pm 1.589^{b}$ \\
\hline
\end{tabular}

Keterangan (Note):

A. Tanpa upaya penumbuhan bioflok (Without an effort to develop bioflok)

B. Diupayakan tumbuh bioflok (With effort to develop biofloc)

juga dilakukan setiap hari sebanyak $4 \mathrm{mg} / \mathrm{L}$, aerasi yang cukup di seluruh permukaan dan kolom air, maka bioflok juga akan cepat terbentuk dan volumenya juga cepat meningkat. Menurut Avnimelech (2009), di air tambak udang umumnya volume bioflok sebanyak 2 $40 \mathrm{~mL} / \mathrm{L}$ dan mencapai $100 \mathrm{~mL} / \mathrm{L}$ di kolam ikan. Sedangkan menurut Nyan Taw (2010), volume bioflok yang ideal untuk tambak udang vaname intensif adalah sebanyak $15 \mathrm{~mL} / \mathrm{L}$. Oleh karena itu, pada penelitian ini bioflok yang terbentuk selalu distabilkan volumenya agar tidak melebihi $15 \mathrm{~mL} / \mathrm{L}$ air tambak, dengan cara mengatur penambahan sumber $\mathrm{C}$ karbohidrat/ molase dilakukan tidak setiap hari lagi setelah bioflok tumbuh padat, tetapi menunda hingga setiap tiga hingga empat hari sekali dan dilakukan penggantian air.

\section{Total Suspended Solid (TSS) dan Volatil Suspended Solid (VSS)}

Padatan tersuspensi total (TSS) adalah bahan-bahan tersuspensi yang tertahan pada saringan millipore dengan diameter pori 0,45 mikron. VSS adalah bahan organik yang teroksidasi pada pemanasan dengan suhu 
$600^{\circ} \mathrm{C}$ (Effendi, 2003). Menurut Avnimelech (2009), nilai TSS normal pada air tambak udang intensif adalah sekitar $50-300 \mathrm{mg} / \mathrm{L}$, sedangkan pada tambak ikan intensif mencapai 1.000 $\mathrm{mg} / \mathrm{L}$. Pada penelitian ini, nilai TSS paling tinggi di tambak yang tidak ditumbuhkan bioflok adalah 102,6 mg/L, sedangkan pada tambak yang ditumbuhkan bioflok 210,6 mg/L (Gambar 3 A). Selanjutnya telah diestimasi bahwa setiap $100 \mathrm{mg}$ TSS/L air tambak adalah sama dengan sekitar $1.000 \mathrm{~kg}$ pakan/ha. Namun demikian berapa persen dari bioflok yang dikonsumsi oleh udang dapat menggantikan posisi pakan buatan, sehingga ada efisiensi biaya produksi dan bagaimana dengan pertumbuhan udang dan nilai konversi pakan. Pertanyaan selanjutnya apakah pakan dengan kandungan protein rendah baik digunakan sebagai pakan udang, setelah flok tumbuh. Dari hasil analisis biokimia, bioflok yang diproduksi di boster menggunakan bak kerucut di laboratorium kandungan proteinnya sebesar 28,73\% dengan kandungan asam amino esensial dan non esensial yang cukup lengkap (Gunarto \& Suryanto, 2011). Namun dari hasil analisis bioflok yang diproduksi pada penelitian ini kandungan proteinnya hanya $20 \%-23 \%$.

Nilai VSS pada awalnya rendah di kedua petak tambak, selanjutnya meningkat di petak $B$ hingga mencapai $21,14 \mathrm{mg} / \mathrm{L}$ pada bulan
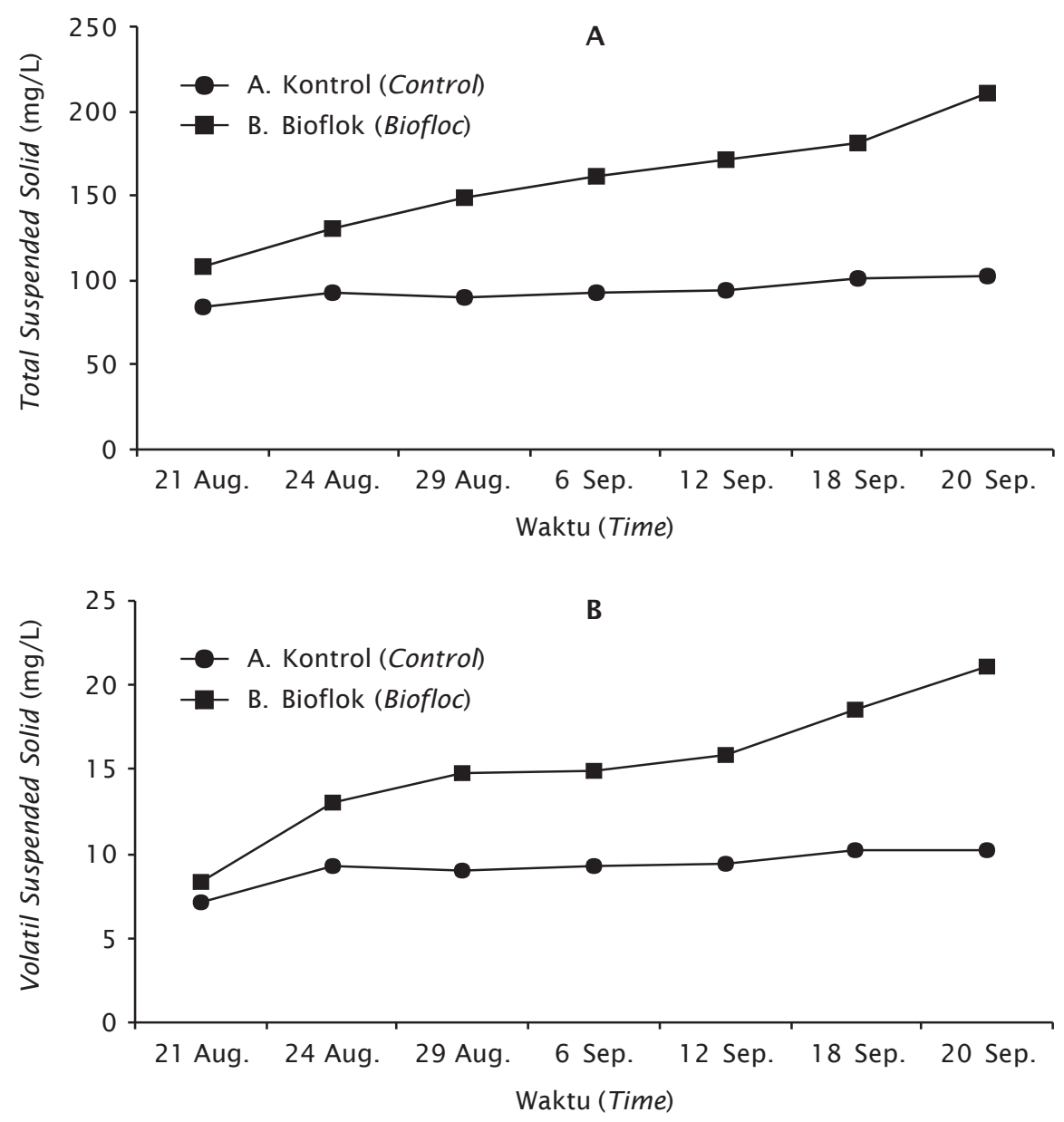

Gambar 3. Nilai Total Suspended Solid (TSS) (A) dan nilai Volatil Suspended Solid (VSS) (B) di tambak kontrol (A) dan di tambak dengan sistem bioflok (B)

Figure 3. TSS value $(A)$ and VSS value $(B)$ in control pond $(A)$ and pond with biofloc systems (B) 
September 2011 menjelang udang dipanen, sedangkan di petak A nilai VSS relatif stabil dan tertinggi hanya mencapai $10,17 \mathrm{mg} / \mathrm{L}$ (Gambar 3 B).

\section{TOTAL HAEMOSIT DAN PROPHENOL OKSIDASE}

Dalam badan udang tidak mempunyai immunoglobulin yang berperan dalam kekebalan, tetapi hanya mempunyai sel haemosit yang merupakan faktor pertahanan seluler dan humoral yang penting sebagai pertahanan badan melawan serangan organisme patogen. Sel haemosit berfungsi fagositose, proses koagulasi, dan pelepasan propenoloksidase, sinthesis alpha-2 makroglobulin dengan glutinin dan peptida anti bakteri Johansen et al., 2000; Bachere, 2000; Gilles \& Haffner, 2000). Sehingga penyebaran dan peningkatan jumlah haemosit merupakan bentuk dari respon imun seluler pada tumbuh udang (Itami, 1994).

Hasil analisis total haemosit pada udang vaname yang dibudidayakan di tambak sistem bioflok (tambak B) menunjukkan bahwa total haemosit jumlahnya lebih banyak daripada total haemosit udang di tambak A (kontrol). Hasil analisis statistik menunjukkan prophenol oksidase udang di tambak B jumlahnya lebih banyak secara signifikan $(P<0,05)$ daripada yang diperoleh di tambak A (kontrol) (Tabel 3). Dengan peran haemosit sebagai faktor kekebalan, maka dibuktikan dengan diperoleh sintasan udang di tambak B lebih tinggi daripada sintasan udang di tambak A. Meningkatnya sel haemosit merupakan indikator meningkatnya ketahanan badan udang terhadap serangan penyakit. Hal tersebut sependapat dengan yang dikemukakan oleh Gunanti (2008).
Prophenol oxidase Activating Enzim (PPA) merupakan pengganti immunoglobulin, adalah protein yang berlokasi di sel granuler haemosit. PPA ini diaktifkan oleh lipopolisaharida dan $\beta$ 1,3 glukan, yang akan merangsang prophenol oksidase menjadi phenol oksidase. Perubahan ini akan dihasilkan protein Opsonin Factor yang dapat menginduksi sel-sel hyalin untuk melakukan proses fagositosis (Johansson \& Soderhall, 1989). Pada introduksi $\beta$ glukan akan terjadi penurunan terhadap jumlah haemosit yang beredar. Setelah penurunan maka akan terjadi perubahan balik secara perlahan-lahan. Pasca perubahan balik, akan terjadi kenaikan haemosit secara drastis (Johansson et al., 2000) dan hal tersebut akan berlaku pada benur vaname yang diberi pakan mengandung $\beta$ glukan. $\beta$ 1,3 glukan juga banyak terkandung pada sel dinding ragi jenis Sacharomyces cerevisiae. Ragi tersebut juga selalu ditambahkan pada waktu membuat fermentasi probiotik yang diaplikasikan pada budidaya udang vaname pola intensif, sehingga diharapkan populasinya akan menjadi banyak dan mampu meningkatkan haemosit udang sehingga meningkatkan kekebalan pada udang yang dibudidayakan.

\section{KESIMPULAN}

Penambahan sumber C-karbohidrat ke air tambak $B$ untuk meningkatkan $\mathrm{CN}$ rasio di air tambak > 10:1, menyebabkan berkembangnya bioflok lebih cepat terbentuk di tambak B. Sintasan dan produksi udang vaname tinggi (70,72\%; 6.717,2 kg/ha), juga nilai konversi pakan rendah $(1: 1,58)$ pada tambak yang ditumbuhkan biofloknya (tambak B). Sedangkan pada tambak kontrol sintasan dan produksi udang vaname rendah $(34,3 \% ; 4.303,9 \mathrm{~kg} / \mathrm{ha})$

Tabel 3. Total haemosit dan prophenol oksidase pada udang dari tambak kontrol (A) dan tambak dengan sistem bioflok (B)

Table 3. Total haemocyte and prophenol oxydase from shrimp in control pond $(A)$ and pond with biofloc systems $(B)$

\begin{tabular}{ccc}
\hline $\begin{array}{c}\text { Perlakuan } \\
\text { Treatments }\end{array}$ & $\begin{array}{c}\text { Total haemosit }(\mathrm{sel} / \mathrm{mL}) \\
\text { Total haemocyte }(\text { cells } / \mathbf{m L})\end{array}$ & $\begin{array}{c}\text { Prophenol oksidase } \\
\text { Prophenol oxydase }\end{array}$ \\
\hline A & $4,400,000 \pm 1,900,000^{\mathrm{a}}$ & $0.0445 \pm 0.035^{\mathrm{a}}$ \\
B & $6,600,000 \pm 540,830^{\mathrm{a}}$ & $0.115 \pm 0.0368^{\mathrm{b}}$ \\
\hline
\end{tabular}

Keterangan (Note):

A. Tanpa upaya penumbuhan bioflok (Without an effort to develop bioflok)

B. Diupayakan tumbuh bioflok (With effort to develop biofloc) 
dan nilai konversi pakan tinggi $(1: 1,82)$. Total haemosit dan prophenol oksidase juga meningkat pada udang yang hidup di tambak yang volume biofloknya lebih tinggi (tambak B) daripada udang yang diambil dari tambak kontrol tidak diupayakan tumbuh bioflok $(\operatorname{tambak} A)$.

\section{DAFTAR ACUAN}

Anonim. 2003. Litopenaeus vannamei sebagai alternatif budidaya udang saat ini. PT Central Proteinaprima (Charoen Pokphand Group) Surabaya, 16 hlm.

Anonim. 2009. Konsep Budidaya Udang Sistem Bakteri Heterotroph dengan Bioflocs. AIYU Shirotabiota Indonesia. Biotechnology Consulting \& Trading Komplek Sapta Taruna PU, Blok B1 No. 13 Bandung, Jawa Barat, Indonesia, $14 \mathrm{hlm}$.

Avnimelech, Y. 1999. Carbon/Nitrogen ratio as control element in aquaculture systems. Aquaculture, 176: 22-235.

Avnimelech, Y. 2007. Feeding with microbial flocs by tilapia in minimal discharge bioflocs technology ponds. Aquaculture, 264: 140-147.

Avnimelech, Y. 2009. Biofloc Technology, A Practical Guide Book. World Aquaculture Society. Baton Rouge, Louisiana, Amerika Serikat, $181 \mathrm{hlm}$.

Bachere, E. 2000. Shrimp immunity and diseases control. Aquaculture, 191: 3-11.

Bagheri, T., Hedayati, S.A., Yavari, V., Alizade, M., \& Farzanfar, A. 2008. Growth, survival and gut microbial load of rainbow trout (Onchorhynchus mykiss) fry given diet supplemented with probiotic during the two months of first feeding. Turk. J. Fish. Aquat. Sci., 8: 43-48.

Blaxhall, P. \& Daishley, K. 1973. Some blood parameters of the Rainbow Trout I. The Kamloops variety, J. Fish. Biol., 5: 1-8.

Bob Rosenberry. 2011 . Shrimp News International, free news page. New release in 2011. Darminto take over big Penaeus monodon farm in Bali since 1988. www.shrimpnews.com, diakses 11 Nopember 2011.

Boyd, C.F. 1990. Water quality in ponds for aquaculture. Auburn University, Alabama USA, $482 \mathrm{pp}$.

Bray, W.A., Lawrence, A.C., \& Leung-Trujillo, J.R. 1994. The effect of salinity on growth and survival of Penaeus vannamei, with obser- vation on interaction of IHHN virus and salinity, Aquaculture, 122: 133-146.

Effendi, H. 2003. Telaah kualitas air bagi pengelolaan sumber daya dan lingkungan perairan. Penerbit Kanisius, Yogyakarta, hlm. 64-66.

Ekasari, J. 2008. Bio-flocs technology: The effect of different carbon source, salinity and the addition of probiotics on the primary nutritional value of the bio-flocs. Thesis Master pada Ghent University, Belgia, 91 pp.

Gilles Le Moullac \& Haffner, P. 2000. Environmental factors affecting immune responses in crustacea. Aquaculture, 191: 121-131.

Gunanti, M. 2008. Respon imun udang windu Penaeus monodon Fabricus yang diimunisasi dengan protein membran imunogenik MP 38 dari Zoothamnium penaei. Prosiding Seminar Nasional Hasil Riset Kelautan dan Perikanan, Fakultas Perikanan dan IImu Kelautan, Universitas Brawijaya, Malang, 8 Nopember 2008, hlm. 22-28.

Gunarto \& Mansyur, A. 2007. Budidaya udang vanamei (Litopenaeus vannamei) di tambak dengan padat tebar berbeda menggunakan sistem pemupukan susulan. J. Ris. Akuakultur, 2(2): 167-176.

Gunarto \& Hendrajat, E.A. 2008. Budidaya udang vanamei, Litopenaeus vannamei pola semi intensif dengan aplikasi beberapa jenis probiotik komersial. J. Ris. Akuakultur, 3(3): 339-349.

Gunarto, Mansyur, A., \& Muliani. 2009. Aplikasi dosis fermentasi probiotik berbeda pada budidaya udang vaname (Litopenaeus vannamei) pola intensif. J. Ris. Akuakultur, 4(2): 241-255.

Gunarto, Muliani, \& Mansyur, A. 2010 a. Pengaruh aplikasi sumber C-karbohidrat (tepung tapioka) dan fermentasi probiotik pada budidaya udang windu, Penaeus monodon pola intensif di tambak. J. Ris. Akuakultur, 5(3): 393-409.

Gunarto, Muliani, \& Mansyur, A. 2010b. Aplikasi produksi bioflok pada budidaya udang windu, Penaeus monodon pola intensif di tambak dasar tanah. Laporan Hasil Penelitian TA. 2010, $11 \mathrm{hlm}$.

Gunarto \& Suwoyo, H.S. 2011 . Produksi bioflok dan nilai nutrisinya dalam skala laboratorium. Prosiding Seminar Forum Inovasi Teknologi Akuakultur, 2011 . Jilid 2, hlm. 1.009-1.017. 
Hari, B., Kurup, B.M., Varghese, J.T., Schrama, J.W., \& Verdegem, M.C.J. 2004. Effects of carbohydrate addition on production in extensive shrimp culture systems. Aquaculture, 241: 179-194.

Itami, T. 1994. Body defense system of penaeid shrimp. Seminar on fish physiology and prevention of epyzootics. Department of Aquaculture and Biology, Shimonoseki University of Fisheries, Japan, 7: 59-65.

Johansson, M.W. \& Soderhall, K. 1989. Cellular immunity in crustacean and the Pro system. Parasitology Today, 5(6): 171-176.

Johansson, M.W., Keyser, P., Sritunyalucksana, K., \& Soderhall, K. 2000. Crustacean haemocyts and haemotopoiesis. Aquaculture, 191: 42-52.

Kartika, A. 2009. Optimum rasio C/N medium dengan penambahan sukrose pada pembentukan bioflok untuk peningkatan kualitas air pada sistem akuakultur. Sekolah Ilmu dan Teknologi Hayati ITB, email : kartikalifl@yahoo.com.

Liu, C.H. \& Chen, J.C. 2004. Effect of ammonia on the immune response of white shrimp Litopenaeus vannamei and its susceptibility to Vibrio alginolyticus. Fish Shellfish Immunol., 16: 321-334.

Matteo, A.A., Giorgia, G., Olivier, D., Pavlos, M., Claudia, B., \& Carnevali, O. 2010. Application of multi-species of Bacillus in sea bream larviculture. Aquaculture, 305: 12-19.

Mclntosh, R.P. 2000. Changing paradigms in shrimp farming. IV. Low protein feeds and feeding strategies. Global Aquaculture ADVOCATE, April 2000, 3(2): 44-50.

Moss, S.M., Divakaran, S., \& Kim, B.G. 2001. Stimulating effects of pond water on digestive enzyme activity in the Pacific white shrimp, Litopenaeus vannamei (Boone). Aquaculture Research, 32(2): 125131.

Nyan Taw. 2010. Recent progress of biofloc technology for sustainable shrimp (pacific white shrimp) eficiency and profitability. International Conference on Shrimp Aquaculture. Universitas Hang Tuah Surabaya, 28-29 Oktober 2010, 36 pp.
Poernomo, A. 2004. Teknologi Probiotik untuk Mengatasi Permasalahan Tambak udang dan Lingkungan Budidaya. Makalah disampaikan pada Simposium Nasional Pengembangan Ilmu dan Inovasi Teknologi dalam Budidaya. Semarang , 27-29 Januari 2004, $24 \mathrm{hlm}$.

Samocha, T.M., Susmita, P., Burger, J.S., Almeida, R.V., Abdul-Mehdi, A., Zarrein, A., Harisanto, M., Horowitz, A., \& Brock, D.L. 2006. Use of molasses as carbon source in limited discharge grow-out systems for Litopenaeus vannamei. Aquaculture America, p. 1-2.

Saenphon, C., Taw, N., Edi, M.H., \& Gunawan, A. 2005. Culture trials on production potential of L. vannamei in heterotropic (bacteria floc) system. Makalah disajikan pada seminar WOC di Bali. Agustus 2005.

Schryver, P.D., Crab, R., Devoirdt, T., Boon, N., $\&$ Verstraete, W. 2008. The basic of bioflocs technolog: The added value for aquaculture. Aquaculture, 227: 125-137.

Smith, D.M., Burford, M.A., Tabrett, S.J., Irvin, S.J., $\&$ Ward, L. 2002. The effects of feeding frequency on water quality and growth of the black tiger shrimp (Penaeus monodon). Aquaculture, 207: 125-136.

Subyakto, S., Dede, S., Afandi, M., \& Sofiati. 2008. Budidaya udang vaname (Litopenaeus vanname) semiintensif dengan metode sirkulasi tertutup untuk menghindari serangan virus. Berkala Ilmiah Perikanan, Program Studi Budidaya Perairan, Fakultas Kedokteran Hewan, Universitas Airlangga, 3(1): 1-8.

Tacon, A.G.J., Cody, J.J., Conquest, L.D., Divakaran, S., Forster, L.P., \& Decamp, O.E., 2002. Effect of culture system on the nutrition and growth performance of Pacific white shrimp Litopenaeus vannamei (Boone) fed different diets. Aquaculture Nutrition, 8(2): 121-137.

Zhi, Y.J., Ian, F., Lytha, C., Warren, D., Wenhoa, C.K., \& Horgen, F.D. 2008. Determination of microbial community structures of shrimp floc cultures by biomarkers and analysis of floc amino acid profiles. Aquaculture Research, 39: 118-133. 